LWSA

PAPER - OPEN ACCESS

\title{
Hasundutan Regency, North Sumatra Province, Indonesia
}

\author{
Author : Liska Simamora \\ DOI $\quad: 10.32734 /$ lwsa.v1i1.155 \\ Electronic ISSN : :2654-7058 \\ Print ISSN : 2654-7066 \\ Volume 1 Issue 1 - 2018 TALENTA Conference Series: Local Wisdom, Social and Arts
}

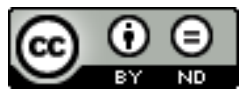

This work is licensed under a Creative Commons Attribution-NoDerivatives 4.0 International License.

Published under licence by TALENTA Publisher, Universitas Sumatera Utara
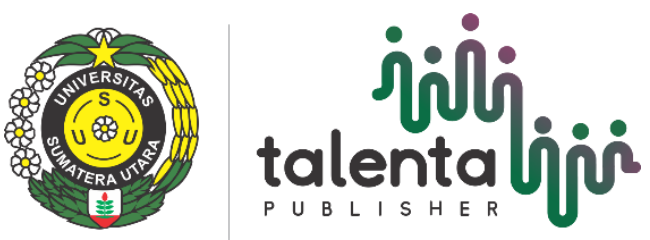


\title{
ijoli talenta i̊ọ TALENTA Conference Series \\ Available online at https://talentaconfseries.usu.ac.id

\section{Hasundutan Regency, North Sumatra Province, Indonesia}

\author{
Liska Simamora $^{a}$, Jun-Yen Lee ${ }^{\mathrm{a}}$, Ching-Hsing Chang ${ }^{\mathrm{a}}$ \\ ${ }^{a}$ College of Management, National Chiayi University, Taiwan 60054
}

abigailliska752@gmail.com

\begin{abstract}
The rapidly population increasing in Indonesia forced the government to create more job opportunities. It was thought that the problem could be solved by developing timber estates in the forestry sector. The plantation effort in the form of HTIs (timber estates) only began in earnest in 1990. Most often, the development projects provide economic benefits and better living environment, but they also affect local people adversely. Social impact assessments help in understanding such impacts. The case study was conducted in North Sumatra Province in Indonesia and involved the stakeholders, they are local community, value chain actors, workers, and the society. This study aims to assess the impacts of Toba Pulp Lestari tbk PT on local community social life; and develops the alternatives to overcome the conflicts happened between the local communities and the company. The impacts are measured based on six constructs of social impact within thirty eight of sub-construct. The result shows the first rank as the most important in the community life aspect is perceived well-being and the second the most important is conservation the community resources occupies the second rank in pairwise comparison table.This study develops alternatives by suggesting Toba Pulp Lestari tbk PT to do environment impact analysis and social impact analysis.
\end{abstract}

Keywords: SIA; construct of SIA; Stakeholders

\section{Introduction}

The population of Indonesia had rapidly increased at the average annual rate of 1.8\% during 1980-1990 as done unemployment. Therefore, the Government recognized that more job opportunities should be created particularly in the private sector. In the forestry sector, it was thought that the problem could be solved by developing timber estates (FAO, 1996). Demand for the paper in the world are increasing. It keeps the pulp \& paper company operating and enlarge its concession. Paper industries generate $2 \%$ of world trade and demand for paper is rising. Paper still represents the primary medium of communication for the majority of people,especially in education, and it has wide commercial uses, including packaging and health care. Nowadays wood is the main row material used for pulp \& paper manufactures in the world. Pulp \& paper industry has significant impacts on people and communities all around the world. It is responsible for violations of land rights in many places where the fiber for paper is sourced, both in natural forests and by the establishment of plantations on land without the consent of local people. The industry has had devastating impacts on local livelihoods by competing for forests and water and harming markets for natural resources (Kinsella et al., 2007). The study site for this research is Humbang Hasundutan regencyProvince of North Sumatera in Indonesia. The regency has considerable natural resources in forests and it is significant for cultural 
development, environment protection, and economic development. The regency covers an area of 251765 , 93ha,and according to thecensus 2010 had a population of 171,687 the latest estimate (for January 2014) is 178,866. In the forestry sector, the Humbang Hasundutan regency has $159.392 \mathrm{Ha}$ of forest land consists of 84.540 ha of production forest; 74.852 ha of protected forest(Statistical Bureau, 2015).In 2009 the government of Humbang Hasundutan Regency issued a license to Toba Pulp Lestari, Tbka pulp and paper mill to manage the area. After obtaining the license, the company cut down the Frankincense trees and finally replaced by eucalyptus trees from which paper can be made. The indigenous people of Pandumaan and Sipituhuta fought back and the company and the government's apparatus responded with violence. On 19 September 2012, the indigenous people of Pandumaan and Sipituhuta clashed with the company's security forces and the Mobile Brigade (Brimob, paramilitary police) guarding the company (Mikkelsen,2013).Various social scientists suggested that the social benefits commonly associated with the projects include improved agricultural yields, and farmer returns, increased access to agricultural water, and new employment opportunity (Ahmadvand \& Karami, 2009). To know the truth of those company impacts into communities social life, this study will apply social impact assessment (SIA) of PT. Toba Pulp Lestari, tbk to the communities in Sipituhuta village. Social impact assessment (SIA) is a tool for assessing and managingthe social consequences of development projects on people (Vanclay, 2005). Its objective is to identify the intended and unintended social impacts of planned interventions in order to develop sustainable management plans (Barrow, 2000). The conflict that is exist between communities and Toba Pulp Lestari tbk PT can be managed in order to get win-win situation.

\section{Research Methods}

The procedure in doing this study, generally follows the Social Impact Assessment (SIA) proposed by Arc-Gomez, et al (2014). This procedure presents the applying of case study following the SIA process. In the first three steps of SIA process (1) Screening (2) community profiling (3) scoping are the preparing for the research strategy in order to prepare for the data collection. The forth step of SIA process (4) assessing impacts 5) Formulating alternatives for the planned intervention (6) Creating mitigation and enhancement strategies and developing a plan to manage social impacts (7) Monitoring of social impacts (8) Management plans and evaluation. There are 18 household leaders to be interviewd as the represents of local community, 3 representative of value chain actors, 2 community leaders and 1 NGO. The sampling technique is snowballing or purposive sampling where the key informants are pointed by the previous information source.

This study uses six social indicators as the measurement. The indicators were weighted by using MCDA (Multi Criteria Decision Analysis) technique. The technique is AHP (Analysis Hierarchy process by using pairwise comparison to list the most and the least important indicator. Further, each item of each criteria was divided in to two time periods, before and after the Toba Pulp Lestari tbk PT operated in order to identify the gap happened between the local community expected and achieved. The gap is generated by finding the different in the Likert scale within two time periods. if the gap between the two time periodes equals zero (0), the currently situation matches the communities expectation, If the gap is positive (+), the currently situation is exceeding the communities expectation. If the gap is negative (-), that means the expectation is opposite.

\section{Results and Discussion}

In the beginning of this chapter, the first result to be shown is the pairwise comparison in order to identify the most and the least important of social indicators in the local community life, based on ten household leaders who have a good reputation within the community. 
Table 1. Pair wise comparison of six social impact indicators.

\begin{tabular}{|c|c|c|c|c|c|c|c|c|}
\hline $\begin{array}{l}\text { An example of a column } \\
\text { heading }\end{array}$ & A & B & $\mathrm{C}$ & D & $\mathrm{E}$ & $\mathrm{F}$ & Total & Rank \\
\hline A & & 1 & 1 & 1 & 1 & 1 & 5 & 1 \\
\hline B & 0 & & 0 & 1 & 0 & 0 & 1 & 5 \\
\hline $\mathrm{C}$ & 0 & 1 & & 1 & 1 & 0 & 3 & 3 \\
\hline D & 0 & 0 & 0 & & 0 & 0 & 0 & 6 \\
\hline E & 0 & 1 & 0 & 1 & & 0 & 2 & 4 \\
\hline F & 0 & 1 & 1 & 1 & 1 & & 4 & 2 \\
\hline
\end{tabular}

Source: Interview with ten households head

$1=$ Important than

$0=$ Less important than,

A: Perceived well-being

B: Social capital

C: Quality of life

D: Social structure development

E: Rural and agricultural economic condition

F: Conservation of community resources

Table 1 shows the result that the local community put the perceived well-being (Rank $A=1)$ to be the most important indicator in their daily life. Based on the interview with the community, that they will not do an opposition with the Toba Pulp Lestari PT if this pulp company guarantee satisfaction to the communities. The local community explained that the manner of Toba Pulp Lestari PT and the government to claim the land consession ignore the community consideration adreessed the community to a unsatisfiction feeling.

Conservation of community resources is stated in the second position (Rank F=2). The local community realizes that the clearing-cut the natural trees include the frankincense will damage not only the environment but also the resources for the community to earn livelihood income. It presents that it is important for the community to protect the natural resources by doing conservation of community resources. The communities also realized that another importance of the conservation of community resources also help the communities to maintain the culture heritage such as the cultivation of the frankincense.

The third, fourth and fiveth position are occupied by indicators the quality of life (Rank c=3); rural and agricultural economic condition (Rank E=4) and the social capital (Rank B=5). The interview result showed that the communities do not expect the Toba Pulp Lestari, PT will fullfil these three indicators because the communities have ability to achieve it.

The least important is social structure development ( $\operatorname{Rank} \mathrm{D}=6$ ). Even though the community admitted that the presence of the politicians who had promised to release the community land ownership have ability to do the land protection, the communities agree that this indicator and its sub-indicators do not necessary to be viewed as the important thing in the communities social life.

\section{Stakeholders Perspective}

\section{Local communities perspectives}

The local communities perspectives are explained by the data shown in Table 2. Measuring the local community based on six social indicators. (1) perceived well-being: The average gap of of each perceived well-being subindicators are $\mathrm{A} 1=-0.44 ; \mathrm{A} 2=-0.17 ; \mathrm{A} 3=-0.78 ; \mathrm{A} 4=-0.56 ; \mathrm{A} 5=-0.11$ confirms that the perceived condition does not meet the expectation in perceived well-being of local community and there is no significant difference between expected and perceived condition within two time periode, before and currently situation when the Toba Pulp Lestari 
PT exsisted in SipituHuta village. This result consistent with the local communities statement said that they do not expect anything for a better life by the presence of the Toba Pulp Lestari tbk PT.(2) social capital: The average gap of of each perceived well-being sub-indicators are $\mathrm{A} 1=-0.44 ; \mathrm{A} 2=-0.17 ; \mathrm{A} 3=-0.78 ; \mathrm{A} 4=-0.56 ; \mathrm{A} 5=-0.11$ confirms that the perceived condition does not meet the expectation in perceived well-being of local community and there is no significant difference between expected and perceived condition within two time periode, before and currently situation when the Toba Pulp Lestari PT exsisted in SipituHuta village. This result consistent with the local communities statement said that they do not expect anything for a better life by the presence of the Toba Pulp Lestari tbk PT.(3) quality of life:The gap in quality of life is relatively small. This result shows that Toba Pulp Lestari PT does not have a significant impact to the local community quality of life. There are eight sub-indicators have the gap value equal zero: sending the children confidently to higher level educatin (C1),increasing of household income (C3), owning livestock farm (C5), Owning agricultural machine (C6), Owning house (C7), having enough food every day (C8), and having nutritious food everyday (C9). The local community informed that there is no a real different that was happened before the Toba Pulp Lestari PT came to the village until recently time related to those eight subindicators. (4)social structure development : The gap within the social structure development sub-indicators shows that there is a signifant different in politics role (D1=3.11). Before the Toba Pulp Lestari PT existent in SipituHuta village, the local community do not pay attention to the political role. In the time periode Toba Pulp Lestari PT have land consession in the local community forest, the local community expect much for the politicians to protect the land ownership right, as those politician candidates always pledge in to the community in the campaign moment.The rest two of the sub-indicators: the religion role $(\mathrm{D} 2=-0.22)$ and the role of the people who have the highest status level (D3= 1.00) show that these two decision makers do not impacted by the existing of Toba Pulp Lestari PT. (5) rural and agricultural economic condition: The gap in the rural and agricultural economic condition impact within two time periode shows that Toba Pulp Lestari PT has a positive impact related to creating the new roads $(E 1=2.27)$ and community ability to assess the new information $(E 2=1.16)$ from outside of the village. Related to the agricultural product selling $(\mathrm{E} 3=0.11)$, this result informs us that the presence of the Toba Pulp Lestari PT does not have a significant impact to the local community agriculture product selling. As mentioned by the local community in the interview time, Toba Pulp Lestari PT does not pay attention to the main sources of the local community livelihood. (6)Conservation of community resources: The big gap within almost all of the indicators tells the truth that Toba Pulp Lestari PT does not pay attention to the local community resources. Naturally damage of the resources such as water availability, quality of water, the increasing of forest product, the condition of soil affect the decreasing and the increasing of agriculture crop in Sipitu Huta village.

Table 2. Social impact indicator, rank,criteria, gap.

\begin{tabular}{|c|c|c|c|c|}
\hline Indicator & Rank & Criteria & Label & Gap Average \\
\hline & & In most ways my life is close to my ideal & A1 & -0.44 \\
\hline & & The condition of my life are excellent & $\mathrm{A} 2$ & -0.17 \\
\hline \multirow[t]{6}{*}{ Perceived Wellbeing } & 1 & I am satisfied with my life & $\mathrm{A} 3$ & -0.78 \\
\hline & & So far I have gotten the important things I want in Life & A4 & -0.56 \\
\hline & & If I could live my life over, I would change almost Nothing & A5 & -0.11 \\
\hline & & Engage in club/organization activity & B1 & -0.28 \\
\hline & & Engage in voting for group`s leader & B2 & -0.11 \\
\hline & & My daily life's decisions are influenced by the Communities & B3 & -0.33 \\
\hline \multirow[t]{6}{*}{ Social Capital } & 5 & In general, i feel secure in my residence & B4 & -2.11 \\
\hline & & I often talk to my neighbours & B5 & -0.94 \\
\hline & & I trust my neighbours & B6 & -2.28 \\
\hline & & I trust the local government policies & B7 & -2.00 \\
\hline & & I trust all the public services & B8 & -0.72 \\
\hline & & I am confidence to send my children to higher level school & $\mathrm{C} 1$ & 0.00 \\
\hline
\end{tabular}




\begin{tabular}{|c|c|c|c|c|}
\hline & & I used hired labourin farm & $\mathrm{C} 2$ & 0.00 \\
\hline & & My income status is getting better & $\mathrm{C} 3$ & 0.00 \\
\hline \multirow[t]{9}{*}{ Quality Of Life } & \multirow[t]{9}{*}{3} & I have my own agriculture farm & $\mathrm{C} 4$ & 0.20 \\
\hline & & I have my own livestock farm & $\mathrm{C} 5$ & 0.00 \\
\hline & & I have agricultural machine(s) & C6 & 0.00 \\
\hline & & I have my own house & $\mathrm{C} 7$ & 0.00 \\
\hline & & My family eat enough foods every day & $\mathrm{C} 8$ & 0.00 \\
\hline & & My family eat nutritious food every day & C9 & 0.00 \\
\hline & & My family buy new clothes every month & $\mathrm{C} 10$ & 0.00 \\
\hline & & My family members use medical insurance service & $\mathrm{C} 11$ & 0.00 \\
\hline & & The politics role is so important & A1 & -0.44 \\
\hline Social Structure & \multirow[t]{3}{*}{6} & The religion role is so important & $\mathrm{A} 2$ & -0.17 \\
\hline \multirow[t]{2}{*}{ Development } & & High statues level has the highest role in decisions Making & A3 & -0.78 \\
\hline & & New roads was built up & E1 & 2.27 \\
\hline Rural and Agricultural & \multirow[t]{5}{*}{4} & Informations access is easier & E2 & 1.16 \\
\hline Economic Condition & & Agricultural product selling is increasing & E3 & 0.11 \\
\hline & & Water ability is sufficient & $\mathrm{F} 1$ & -4.00 \\
\hline & & Water quality is good & $\mathrm{F} 2$ & -4.00 \\
\hline & & Forest production is increasing & $\mathrm{F} 3$ & -3.78 \\
\hline \multirow{5}{*}{$\begin{array}{l}\text { Conservation of } \\
\text { Community } \\
\text { Resources }\end{array}$} & \multirow[t]{5}{*}{2} & Forest sustainability is protected & $\mathrm{F} 4$ & -3.78 \\
\hline & & Soil condition is protected & F5 & -4.00 \\
\hline & & Irrigated area is protected & F6 & -4.00 \\
\hline & & Hunting animal is decreasing & F7 & -1.22 \\
\hline & & $\begin{array}{l}\text { There is a government and company program to engage the } \\
\text { communities to protect the forest }\end{array}$ & F8 & -0.44 \\
\hline
\end{tabular}

\section{Value Chain Actors Perspective}

The only one actors that have been interviewed in this study is transporters. There are three transporters from a different two companies gave information related to the presence of Toba Pulp Lestari PT. The three participants information is shown in appendix list.

The three participants haul the eucalyptus logs from the land consession to the mill centre of Toba Pulp Lestari PT in different regency with SipituHuta village needs three hours to reach. Their perception about Toba Pulp Lestari PT is different with the local community, which, according to them, that Toba Pulp Lestari PT well-operated. However, they suggest that Toba Pulp Lestari PT needs to give more attentions to the local community social welfare by helping the local community to access agricultura facility such as fertilizer, seedling, agricultural equipment (machine).

\section{Worker}

Most of the workers age are between 25-35 years old. According to them, that Toba Pulp Lestari PT has an important role to help their household to meet the family daily needs. According to them, that the presence of the eucalyptus in the land consession has no affect to the soil, water, but has effect to the changing of biodiversity.

\section{Society}

In Sipituhuta village, there are three households that surely confess there is no impact of Toba Pulp Lestari PT to their income because those households do not have frankincense forest land to be cleared cut by the Toba Pulp Lestari 
PT. But, environmentally, they explained about the same impact with another local community that there are some changing in the water availability and water quality, and the changing of the farming land soil.

\section{Conclusion}

In this study the community grievances toward Toba Pulp Lestari tbk PT were caused by two main reasons. First the loosing of livelihood main source, in this case is natural frankincense trees. Second the environmental damage caused by the presence of -alienllspecies in the area named eucalyptus trees . The presence of Toba Pulp Lestari tbk PT in Sipituhuta village Does not meet the local community expectation on perceived well-being, conservation of community resources and social capital.

This study is just the beginning of this area so that, the lack of this study to identify more the actors of stakeholders drives a possibility for a further research in identifying another perspective. If the Toba Pulp Lestari tbk PT plans to renew the forest management policy, they need to involve the community to create a new decision by applying free, priority, informed and consent (FPIC) principle.

\section{References}

[1] Ahmadvan. M \& Karami, E. 2009. A Social impact assessment of the floodwater spreading project on the Gareh-Bygone plain in Iran: A causal comparative approach. Environmental Impact Assessment Review. 29: 126-136.

[2] Arce-Gomez, A., Donovan J.D.,Bedggood R.E. 2015. Social impact assessment: Developing a consolidated conceptual framework. Environmental Impact Assessment Review. 50: 85-94.

[3] Barrow CJ. Social impact assessment: an introduction. London: Arnold; 2000.

[4] FAO. 1996. Indonesian Forestry: Status and Trend. Country report-Indonesia. FAO CORPORATE DOCUMENT REPOSITORY.

[5] Kinsella S. et al., 2007. The State of the Paper Industry Monitoring the Indicators of Environmental Performance, A collaborative report by the Steering Committee of the Environmental Paper Network: Environmental Paper Network-USA.

[6] Mikkelsen C. 2013. The Indigenous World 2013: Copenhagen-Denmark.

[7] Statistical Bureau. 2015. HumbangHasundutan Regency in Figures. HumbangHasundutan-Indonesia.

[8] Vanclay F. 2005. Principles for social impact assessment: A critical comparison between the international and US documents. Environmental Impact Assessment Review. 26: 3-14. 